\title{
Decontamination of High-Risk Animal and Zoonotic Pathogens
}

Hendrik Frentzel, Andrea Menrath, Katharina Tomuzia, Juliane Braeunig, and Bernd Appel

Preparedness for the decontamination of affected environments, premises, facilities, and products is one prerequisite for an immediate response to an animal disease outbreak. Various information sources provide recommendations on how to proceed in an outbreak situation to eliminate biological contaminants and to stop the spread of the disease. In order to facilitate the identification of the right decontamination strategy, we present an overview of relevant references for a collection of pathogenic agents. The choice of pathogens is based on a survey of lists containing highly pathogenic agents and/or biological agents considered to be potential vehicles for deliberate contamination of food, feed, or farm animals. European legislation and guidelines from national and international institutions were screened to find decontamination protocols for each of the agents. Identified recommendations were evaluated with regard to their area of application, which could be facilities and equipment, wastes, food, and other animal products. The requirements of a disinfectant for large-scale incidents were gathered, and important characteristics (eg, inactivating spectrum, temperature range, toxicity to environment) of the main recommended disinfectants were summarized to assist in the choice of a suitable and efficient approach in a crisis situation induced by a specific high-risk animal or zoonotic pathogen. The literature search revealed numerous relevant recommendations but also legal gaps for certain diseases, such as $\mathrm{Q}$ fever or brucellosis, and legal difficulties for the use of recommended disinfectants. A lack of information about effective disinfectants was identified for some agents.

L ARGE-SCALE ANIMAL DISEASE OUTBREAKS can cause high losses of farm animals, challenge public and animal health, and lead to tremendous economic damage. In addition to direct losses caused by the culling of animals, closure of farms, establishment of permanent exclusion zones, trade restrictions, and the disposal of products, there are also indirect negative effects including losses in the tourism industry and reluctant consumer behavior in purchasing animal products. The outbreak of foot-and-mouth disease in the UK in 2001, ${ }^{1,2}$ the avian influenza epidemic in $2003,{ }^{3}$ and the Q fever incidents in the Netherlands from 2007 to $2009^{4}$ illustrate these effects. Besides the risk of a natural or accidental dissemination of a disease, highly pathogenic biological agents (ie, viruses, bacteria, toxins) capable of causing animal diseases or zoonoses are also considered as having potential for a deliberate release.

Regardless of the cause of an incident, a rapid containment of the disease spread is crucial to mitigate the possible consequences. Along with other measures, decontamination of affected environments, premises, facilities, and products is a major issue. Decontamination in this context can be defined as a technical process including all stages of cleaning and disinfection to reduce biological contamination to a harmless level. ${ }^{5,6}$ The appropriate

Hendrik Frentzel, Dr. Andrea Menrath, and Dr. Katharina Tomuzia are Research Scientists; Dr. Juliane Braeunig is Head of the Microbial Toxins Unit; and Prof. Bernd Appel is Head of the Department; all in the Department of Biological Safety, Federal Institute for Risk Assessment (BfR), Berlin, Germany. 
decontamination strategies and capacities should be in place for immediate action in a crisis situation. This aspect is also taken into consideration in the European Union's Action Plan on chemical, biological, radiological, and nuclear security (EU CBRN Action Plan): In Horizontal Action 41, it is stated that member states should assess available means for decontamination of CBRN materials and exchange information about current decontamination procedures. $^{\text {? }}$

The aim of this article is to provide an overview of recommendations for various application fields of decontamination of high-priority animal and zoonotic pathogens in a European context. Relevant information sources are presented for a number of biological agents. Moreover, important parameters of recommended chemical disinfectants are summarized to support the decision for the appropriate disinfection procedure. Along with improved data availability, a comparison between existing decontamination strategies for specific pathogens and toxins of concern with regard to natural, accidental, or criminal incidents could reveal needs for further investigation or recommendations.

\section{Methods}

In order to collect decontamination data on high-risk animal or zoonotic pathogens, this group of pathogens needs to be further defined. Therefore, numerous documents containing lists of pathogens with the potential to cause large-scale animal or zoonotic diseases and/or being suitable for a deliberate contamination were evaluated. ${ }^{8-30}$ Choosing the most frequently named biological agents capable of causing animal or zoonotic diseases, a list of 23 priority pathogens was compiled (Table 1). The list includes highly pathogenic bacteria such as Bacillus anthracis and Yersinia pestis, viruses like foot-and-mouth disease virus, and toxins like Clostridium botulinum neurotoxins (BoNT).

Focusing on these agents, a survey on decontamination procedures was conducted. As a starting point, European legislation was screened, beginning at more general rules ${ }^{31-36}$ and moving on to disease-specific directives. ${ }^{24,37-43}$ The search was compiled in EUR-Lex ${ }^{44}$ for the keywords "decontamination," "disinfection," "hygiene," "by-products," and "animal disease" and combinations thereof, the names of the listed agents, and the names of the induced diseases, if relevant. Moreover, compilations of veterinary legislation were screened. ${ }^{45}$ Besides the focus on decontamination protocols, legislative gaps for the control of animal diseases were identified and legal barriers for the use of disinfectants were revealed.

Because legislative information on a number of diseases such as Q fever and brucellosis was missing and because of the quite general character of the given legal references, a survey regarding more specific protocols was conducted by an internet query using the keywords mentioned above. The following guidelines for decontamination from national or international institutions were identified and reviewed:

- Guideline on Means and Procedures for the Disinfection of Notifiable Animal Diseases, German Federal Ministry of Food, Agriculture and Consumer Protection (BMELV), 2007 (in German); ${ }^{46}$

- Animal Health Australia. Operational Procedures Manual: Decontamination (Version 3.2). Australian Veterinary Emergency Plan (AUSVETPLAN), Edition 3, Primary Industries Ministerial Council, 2008; ${ }^{6}$

- Manual on Procedures for Disease Eradication by Stamping Out, Part 3: Decontamination Procedures, Food and Agriculture Organization of the United Nations (FAO), 2001; ${ }^{47}$

- Technical Factsheets, Center for Food Security \& Public Health, Iowa State University; ${ }^{48}$

- Technical Disease Cards, World Organisation of Animal Health (OIE), 2012; ${ }^{49}$ and

- Terrestrial Animal Health Code, World Organisation of Animal Health (OIE), 2012. ${ }^{50}$

Each of the identified sources that contains relevant information was assigned to the specific agents in Table 1 . The recommendations were assessed with regard to their focus of application to facilities/equipment, wastes of animal husbandry, food products, and/or other animal products (eg, wool, hides, bonemeal) as indicated in Table 1 .

Moreover, the demands for an ideal disinfectant were gathered with regard to the characteristics of large-scale outbreaks or bioterrorism incidents. In view of these demands, parameters were collected that influence the choice of a disinfectant according to situational efficiency (eg, application range or handling conditions) and respective characteristics of the most prevalent disinfectants were summarized (Table 2).

\section{Results}

The search for recommendations for decontamination procedures revealed several legislative references as well as guidelines from national and international institutions but also information gaps and legal restrictions for the use of particular disinfectants. In addition to the overview of information sources, important demands on disinfectants are presented together with decisive characteristics of the main recommended chemical substances.

\section{Legislation}

The review of legislation on decontamination generated general and disease-specific references, which are treated separately in the following sections according to their regulatory contents. 
DECONTAMINATION OF ANIMAL AND ZOONOTIC PATHOGENS

Table 1. References Providing Information for the Decontamination of Specific Biological Agents

\begin{tabular}{|c|c|c|c|c|c|c|c|}
\hline Biological Agent & $\begin{array}{c}B M E L V^{46} \\
(F a, W a)\end{array}$ & $\begin{array}{c}\text { AUSVETPLAN } \\
(\mathrm{Fa}, \mathrm{Wa})\end{array}$ & $\begin{array}{c}F A O^{47} \\
(F a, W a)\end{array}$ & $\begin{array}{c}\text { OIE } C a r d s^{49} \\
(F a, W a \\
F P, A P) \\
\end{array}$ & $\begin{array}{c}\text { Iowa State }{ }^{48} \\
(F a, W a \\
F P, A P) \\
\end{array}$ & $\begin{array}{c}\text { OIE Code } e^{50} \\
(W a \\
F P, A P) \\
\end{array}$ & EU Legislation \\
\hline African swine fever virus & $\mathrm{x}$ & $\mathrm{x}$ & $\mathrm{x}$ & $\mathrm{x}$ & $\mathrm{x}$ & $(\mathrm{x})^{\mathrm{a}}$ & $\begin{array}{l}\text { CD 2002/60/EC } 39 \\
\text { CD 2002/99/EC } \\
\end{array}$ \\
\hline $\begin{array}{l}\text { Avian influenza virus, } \\
\text { high pathogenic }\end{array}$ & $\mathrm{x}$ & $\mathrm{x}$ & $\mathrm{x}$ & $\mathrm{x}$ & $\mathrm{x}$ & $\mathrm{x}$ & $\begin{array}{l}\text { CD } 2005 / 94 / \mathrm{EC}^{41} \\
\text { CD } 2002 / 99 / \mathrm{EC}^{36}\end{array}$ \\
\hline Bacillus anthracis & $\mathrm{x}$ & $\mathrm{x}$ & & & $\mathrm{x}$ & $\mathrm{x}$ & \\
\hline Bluetongue virus & $\mathrm{x}$ & $\mathrm{x}$ & $\mathrm{x}$ & $\mathrm{x}$ & $\mathrm{x}$ & $\mathrm{x}$ & $\begin{array}{l}\text { CD } 2000 / 75 / \mathrm{EC}^{43} \\
\mathrm{CD} 1266 / 2007 / \mathrm{EC}^{37} \\
\mathrm{CD} 92 / 119 / \mathrm{EC}^{24}\end{array}$ \\
\hline Brucella spp. & $\mathrm{x}$ & $\mathrm{x}$ & & & $\mathrm{x}$ & $(\mathrm{x})^{\mathrm{a}}$ & \\
\hline Burkholderia mallei & $\mathrm{x}$ & $\mathrm{x}$ & & $\mathrm{x}$ & $\mathrm{x}$ & $(\mathrm{x})^{\mathrm{a}}$ & \\
\hline Burkholderia pseudomallei & & & & & $\mathrm{x}$ & & \\
\hline Classical swine fever virus & $\mathrm{x}$ & $\mathrm{x}$ & $\mathrm{x}$ & $\mathrm{x}$ & $\mathrm{x}$ & $\mathrm{x}$ & $\begin{array}{l}\text { CD } 2001 / 89 / \mathrm{EC}^{38} \\
\mathrm{CD} 2002 / 99 / \mathrm{EC}^{36}\end{array}$ \\
\hline Clostridium botulinum toxins & & & & & $\mathrm{x}$ & & \\
\hline Coxiella burnetii & & & & & $\mathrm{x}$ & & \\
\hline $\begin{array}{l}\text { Eastern equine } \\
\text { encephalitis virus }\end{array}$ & $\mathrm{x}$ & $\mathrm{x}$ & & & $\mathrm{x}$ & $(\mathrm{x})^{\mathrm{a}}$ & \\
\hline $\begin{array}{l}\text { Enterohemorrhagic } \\
\quad \text { E. coli, O157:H7 }\end{array}$ & & & & & $\mathrm{x}$ & & \\
\hline $\begin{array}{l}\text { Foot-and-mouth } \\
\text { disease virus }\end{array}$ & $\mathrm{x}$ & $\mathrm{x}$ & $\mathrm{x}$ & $\mathrm{x}$ & $\mathrm{x}$ & $\mathrm{x}$ & $\begin{array}{l}\text { CD } 2003 / 85 / \mathrm{EC}^{40} \\
\mathrm{CD} 2002 / 99 / \mathrm{EC}^{36}\end{array}$ \\
\hline Francisella tularensis & & & & & $\mathrm{x}$ & $(\mathrm{x})^{\mathrm{a}}$ & \\
\hline Goat pox virus & $\mathrm{x}$ & $\mathrm{x}$ & $\mathrm{x}$ & $\mathrm{x}$ & $\mathrm{x}$ & $(\mathrm{x})^{\mathrm{a}}$ & $\mathrm{CD} 92 / 119 / \mathrm{EC}^{24}$ \\
\hline Newcastle disease virus & $\mathrm{x}$ & $\mathrm{x}$ & $\mathrm{x}$ & $\mathrm{x}$ & $\mathrm{x}$ & $\mathrm{x}$ & $\begin{array}{l}\text { CD 92/66/EC } \\
\text { CD 2002/99/EC }\end{array}$ \\
\hline $\begin{array}{l}\text { Peste des petits } \\
\quad \text { ruminants virus }\end{array}$ & $\mathrm{x}$ & $\mathrm{x}$ & $\mathrm{x}$ & $\mathrm{x}$ & $\mathrm{x}$ & $(\mathrm{x})^{\mathrm{a}}$ & $\begin{array}{l}\text { CD 92/119/EC } 24 \\
\text { CD 2002/99/EC }\end{array}$ \\
\hline Rinderpest virus & $\mathrm{x}$ & $\mathrm{x}$ & $\mathrm{x}$ & $\mathrm{x}$ & $\mathrm{x}$ & $\mathrm{x}$ & $\begin{array}{l}\text { CD 92/119/EC } 24 \\
\text { CD 2002/99/EC }\end{array}$ \\
\hline $\begin{array}{l}\text { Staphylococcal } \\
\quad \text { enterotoxin B (SEB) }\end{array}$ & & & & & $\mathrm{x}$ & & \\
\hline $\begin{array}{l}\text { Venezuelan equine } \\
\text { encephalitis virus }\end{array}$ & $\mathrm{x}$ & $\mathrm{x}$ & & $\mathrm{x}$ & $\mathrm{x}$ & $(\mathrm{x})^{\mathrm{a}}$ & \\
\hline Vesicular stomatitis virus & $\mathrm{x}$ & $\mathrm{x}$ & $\mathrm{x}$ & $\mathrm{x}$ & $\mathrm{x}$ & $(\mathrm{x})^{\mathrm{a}}$ & $\mathrm{CD} 92 / 119 / \mathrm{EC}^{24}$ \\
\hline $\begin{array}{l}\text { Western equine } \\
\text { encephalitis virus }\end{array}$ & $\mathrm{x}$ & $\mathrm{x}$ & & & $\mathrm{x}$ & $(\mathrm{x})^{\mathrm{a}}$ & \\
\hline Yersinia pestis & & & & & $\mathrm{x}$ & & \\
\hline
\end{tabular}

Note: Focus of application of the given sources: $\mathrm{Fa}=$ facilities/equipment; Wa = wastes of animal husbandry; $\mathrm{FP}=$ food products; $\mathrm{AP}=$ other animal products.

${ }^{a}$ Agent is considered in the specific source, but the provisions on decontamination are negligible to nonexistent. 
FRENTZEL ET AL.

Table 2. Characteristics of Important Chemical Disinfectants with References

\begin{tabular}{|c|c|c|c|c|c|c|c|}
\hline \multirow{2}{*}{$\begin{array}{l}\text { Active } \\
\text { Substance }\end{array}$} & \multirow[b]{2}{*}{ Spectrum } & \multirow{2}{*}{$\begin{array}{l}\text { Effective } \\
\text { pH-range }\end{array}$} & \multicolumn{4}{|c|}{ Temperature Range $\left(\right.$ in ${ }^{\circ} \mathrm{C}$ ) } & \multirow[b]{2}{*}{ Inhibitors } \\
\hline & & & 20 to 10 & 10 to 4 & 0 to -5 & -5 to -30 & \\
\hline $\begin{array}{l}\text { Aldehydes } \\
\text { (glutaraldehydes, } \\
\text { formaldehydes) }\end{array}$ & $\begin{array}{l}\text { Bacteria, }{ }^{1,2,5,6} \\
\text { viruses }{ }^{1,2,6} \\
\text { (selective), }{ }^{2} \\
\text { spores (in higher } \\
\text { concentrations) }{ }^{1,2}\end{array}$ & broad $^{2,5}$ & $\begin{array}{l}\text { limited effective }{ }^{1} \\
\text { (higher } \\
\text { concentrations } \\
\text { needed) }{ }^{2}\end{array}$ & ineffective $^{1,2}$ & ineffective $^{1,2}$ & ineffective $^{1,2}$ & \\
\hline $\begin{array}{l}\text { Sodium } \\
\text { hydroxide }\end{array}$ & $\begin{array}{l}\text { bacteria }^{1,2,5,6} \text { (except } \\
\text { mycobacteria } \\
\text { and surfaces) }^{1,2} \\
\text { viruses }^{1,2,5,6}\end{array}$ & $\begin{array}{l}\text { narrow, } \\
\mathrm{pH} \geq 12^{1,2}\end{array}$ & effective $^{1,2}$ & effective $^{1,2}$ & $\begin{array}{l}\text { limited } \\
\text { effective }^{1} \\
\text { (ineffective) }^{2}\end{array}$ & $\begin{array}{l}\text { limited } \\
\text { effective }^{1} \\
\text { (ineffective) }^{2}\end{array}$ & acids $^{6}$ \\
\hline Limemilk & $\begin{array}{l}\text { bacteria (except } \\
\text { mycobacteria) } \\
\text { viruses }^{1,2,5}\end{array}$ & & effective $^{2}$ & effective $^{2}$ & effective $^{2}$ & $\begin{array}{l}\text { effective } \\
\left.\text { (to }-10^{\circ} \mathrm{C}\right)^{2}\end{array}$ & acids $^{6}$ \\
\hline $\begin{array}{l}\text { Alcohols } \\
\text { (eg,ethanol, } \\
\text { isopropanol) }\end{array}$ & $\begin{array}{l}\text { bacteria, viruses } \\
\text { (selective, } \\
\text { only enveloped) }^{1,2}\end{array}$ & broad $^{2}$ & effective $^{1}$ & $\begin{array}{l}\text { slightly } \\
\text { limited } \\
\text { effective }^{1}\end{array}$ & $\begin{array}{l}\text { slightly } \\
\text { limited } \\
\text { effective }^{1}\end{array}$ & ineffective $^{1}$ & \\
\hline $\begin{array}{l}\text { Sodium } \\
\text { hypochlorite } \\
(\mathrm{NaOCl})\end{array}$ & $\begin{array}{l}\text { bacteria, } \\
\text { viruses, spores }\end{array}$ & $\begin{array}{l}\text { moderate (best: } \\
\mathrm{pH} \mathrm{6-8.5,} \mathrm{loss} \\
\text { of activity } \\
>\mathrm{pH} 8.5)^{5} \\
(\mathrm{pH} 4-8.5)^{2}\end{array}$ & effective $^{1}$ & $\begin{array}{l}\text { limited } \\
\text { effective }^{1}\end{array}$ & ineffective $^{1}$ & ineffective $^{1}$ & thiosulfate ${ }^{5}$ \\
\hline $\begin{array}{l}\text { Iodine }\left(\mathrm{J}_{2}\right) \text {, } \\
\text { Iodophors }\end{array}$ & $\begin{array}{l}\text { bacteria, } \\
\text { viruses, } \\
\text { spores }^{2,6} \\
\text { (poor activity } \\
\text { against spores) }\end{array}$ & 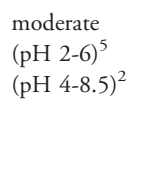 & effective $^{1}$ & effective $^{1}$ & low effective ${ }^{1}$ & low effective ${ }^{1}$ & $\begin{array}{l}\text { hard water, } \\
\text { sodium } \\
\text { thiosulfate }^{5}\end{array}$ \\
\hline $\begin{array}{l}\text { Organic acids } \\
\text { (eg, formic acid, } \\
\text { citric acid, } \\
\text { propionic acid) }\end{array}$ & $\begin{array}{l}\text { bacteria (except } \\
\text { mycobacteria), }{ }^{2} \\
\text { viruses } 2,6\end{array}$ & 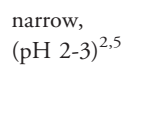 & $\begin{array}{l}\text { slightly limited } \\
\text { effective }^{1} \text { (higher } \\
\text { concentrations } \\
\text { needed) }{ }^{2}\end{array}$ & $\begin{array}{l}\text { limited effective }^{1} \\
\text { (ineffective } \\
\text { except for } \\
\text { mixtures) }\end{array}$ & ineffective $e^{1,2}$ & ineffective $^{1,2}$ & $\begin{array}{l}\text { cationic } \\
\text { surfactants, }^{5} \\
\text { alkalis }^{6}\end{array}$ \\
\hline Peracetic acid & $\begin{array}{l}\text { bacteria, viruses, } \\
\text { spores }^{1,2,5} \text { (also } \\
\text { inactivating } \\
\text { Clostridium } \\
\text { toxins) }^{1}\end{array}$ & 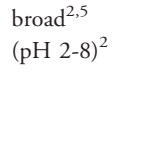 & effective $^{1,2}$ & effective $^{1,2}$ & $\begin{array}{l}\text { effective }^{1} \\
\text { (effective } \\
\text { with } \\
\text { antifreeze) }^{2}\end{array}$ & $\begin{array}{l}\text { effective }^{1} \\
\text { (effective } \\
\text { with } \\
\text { antifreeze) })^{2}\end{array}$ & $\begin{array}{l}\text { copper, iron, } \\
\text { manganese } \\
\text { and chloride } \\
\text { ions } 5\end{array}$ \\
\hline $\begin{array}{l}\text { Phenols } \\
\text { and phenol } \\
\text { derivatives (eg, } \\
\text { phenols, cresols) }\end{array}$ & $\begin{array}{l}\text { bacteria }^{1,2,6} \text { (except } \\
\text { mycobacteria), }{ }^{1} \\
\text { viruses (selective, } \\
\text { only enveloped) }{ }^{1,2,6}\end{array}$ & broad $^{2}$ & effective $^{1}$ & $\begin{array}{l}\text { slightly } \\
\text { limited } \\
\text { effective }^{1}\end{array}$ & ineffective $^{1}$ & ineffective $^{1}$ & \\
\hline $\begin{array}{l}\text { Quaternary } \\
\text { ammonium } \\
\text { compounds } \\
\text { (eg, } \\
\text { benzalkonium) }\end{array}$ & $\begin{array}{l}\text { bacteria (except } \\
\text { mycobacteria } \\
\text { and some } \\
\text { Gr- bacteria), } \\
\text { viruses (selective, } \\
\text { only enveloped) }\end{array}$ & 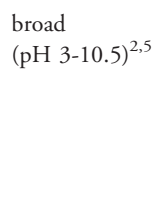 & effective $^{4}$ & effective $^{4}$ & ineffective $^{5}$ & ineffective $^{5}$ & $\begin{array}{l}\text { hard water, } \\
\text { anionic } \\
\text { detergents, } \\
\text { wetting } \\
\text { agents } 5\end{array}$ \\
\hline
\end{tabular}

${ }^{1}=$ Biological Hazards I, Manual for Civil Protection (BBK, RKI). ${ }^{5}$

${ }^{2}=$ Guideline on means and procedures for the disinfection of notifiable animal diseases (BMELV). ${ }^{46}$

${ }^{3}=$ Special Issue "Disinfection" (DVG).$^{54}$

Volume 11, Supplement 1, 2013 
DECONTAMINATION OF ANIMAL AND ZOONOTIC PATHOGENS

Table 2. (Continued)

\begin{tabular}{|c|c|c|c|c|c|c|}
\hline $\begin{array}{l}\text { Sensitivity Against } \\
\text { Organic } \\
\text { Matter }\end{array}$ & $\begin{array}{l}\text { Health Aspects } \\
\text { (using working } \\
\text { solutions, not } \\
\text { concentrates) }\end{array}$ & $\begin{array}{l}\text { Toxicity to } \\
\text { Environment }\end{array}$ & $\begin{array}{l}\text { Material } \\
\text { Tolerance }\end{array}$ & $\begin{array}{l}\text { Stability } \\
\text { of Working } \\
\text { Solution }\end{array}$ & Reaction Time & Costs \\
\hline $\begin{array}{l}\text { low }^{3,5} \\
\text { (protein }^{1} \\
\text { error) }\end{array}$ & $\begin{array}{l}\text { Glutaraldehyde: avoid } \\
\text { eye and skin contact } \\
\text { Formalin solution: } \\
\text { avoid eye and skin } \\
\text { contact; releases toxic } \\
\text { gas, irritant to } \\
\text { respiratory tract and } \\
\text { mucous membranes } \\
\text { Formaldehyde gas: very } \\
\text { toxic to mucous } \\
\text { membranes at } \\
\text { concentrations down to } \\
2 \text { ppm }^{5}\end{array}$ & moderate $^{5}$ & $\begin{array}{l}\text { noncorrosive } \\
\text { (formaldehyde gas } \\
\text { corrosive to some metals) }\end{array}$ & $\begin{array}{l}>7 \text { days in sealed } \\
\text { containers } 5\end{array}$ & $\begin{array}{l}\text { Formaldehyde: } \\
\text { very slow }{ }^{1} \\
\text { (slow) }^{2} \\
\text { Glutaraldehyde: } \\
\text { slow }^{1} \text { (fast }^{2}\end{array}$ & $\begin{array}{l}\text { Formaldehyde: } \\
\text { low } \\
\text { Glutaraldehyde: } \\
\text { high }^{5}\end{array}$ \\
\hline low 5 & $\begin{array}{l}\text { irritant to eyes, skin, and } \\
\text { mucous membranes }\end{array}$ & high $^{5}$ & $\begin{array}{l}\text { highly corrosive to } \\
\text { aluminium, } \\
\text { corrosive to } \\
\text { metal alloys } 5\end{array}$ & $>7$ days $^{5}$ & slow $^{5}$ & low ${ }^{5}$ \\
\hline low ${ }^{5}$ & $\begin{array}{l}\text { irritant to eyes, skin, } \\
\text { and mucous } \\
\text { membranes }\end{array}$ & high $^{5}$ & stains surfaces ${ }^{5}$ & $>7$ days $^{5}$ & slow $^{5}$ & low ${ }^{5}$ \\
\hline low $^{2}$ & $\begin{array}{l}\text { low toxicity to humans; } \\
\text { used as hand } \\
\text { disinfectant }^{1}\end{array}$ & low ${ }^{3}$ & & $>7$ days & very fast ${ }^{1,2}$ & $\operatorname{high}^{3}$ \\
\hline $\operatorname{high}^{1,5}$ & $\begin{array}{l}\text { irritant to eyes and } \\
\operatorname{skin}^{5}\end{array}$ & $\begin{array}{l}\text { low (toxic to fish but } \\
\text { rapidly neutralized by } \\
\text { organic matter) }^{5}\end{array}$ & $\begin{array}{l}\text { corrosive to } \\
\text { metal alloys } 5\end{array}$ & 1 day $^{5}$ & $\operatorname{slow}^{1}{\text { (fast })^{2}}^{2}$ & low $^{5}$ \\
\hline $\operatorname{high}^{3,6}$ & $\begin{array}{l}\text { low toxicity to humans; } \\
\text { used as hand } \\
\text { disinfectant }^{6}\end{array}$ & moderate $^{5}$ & $\begin{array}{l}\text { corrosive to metal and } \\
\text { concrete at acidic } \\
\mathrm{pH} \text { and at high } \\
\text { temperatures }\left(>40^{\circ} \mathrm{C}\right),{ }^{3,5} \\
\text { can cause staining of } \\
\text { skin and synthetic } \\
\text { materials }\end{array}$ & 5 days $^{5}$ & fast $^{2}$ & high $^{5}$ \\
\hline $\operatorname{low}^{5}$ & $\begin{array}{l}\text { irritant to eyes, skin, } \\
\text { and respiratory } \text { tract }^{5}\end{array}$ & low ${ }^{5}$ & low corrosive to concrete ${ }^{5}$ & $>7$ days $^{5}$ & fast $^{1,2}$ & \\
\hline $\begin{array}{l}\text { low }^{1} \text { (except } \\
\text { blood })^{2} \text { (low } \\
\text { to moderate) } \\
3,5\end{array}$ & $\begin{array}{l}\text { reasonable care } \\
\text { necessary }\end{array}$ & $\begin{array}{l}\text { low }^{1,5} \\
{\text { (biodegradable })^{1}}^{1}\end{array}$ & $\begin{array}{l}\text { low corrosive to concrete, } \\
\text { rubber, metal alloys, } \\
\text { without buffering } \\
\text { substances, higher } \\
\text { corrosive to base metals }{ }^{1}\end{array}$ & 1 day $^{2}(1-3 \text { days })^{5}$ & very fast ${ }^{1}$ (fast) $)^{2}$ & $\begin{array}{l}\operatorname{high}^{5} \\
(\text { moderate })^{1}\end{array}$ \\
\hline low $^{1,6}$ & toxic to humans ${ }^{1}$ & $\begin{array}{l}\text { high (poorly } \\
\text { biodegradable) }{ }^{1}\end{array}$ & $\begin{array}{l}\text { relatively noncorrosive, } \\
\text { but absorbed by rubber } \\
\text { and some plastics }{ }^{6}\end{array}$ & & $\operatorname{slow}^{1}$ (fast) ${ }^{2}$ & \\
\hline $\begin{array}{l}\text { high }^{1,3} \\
{\text { (moderate })^{5}}^{\text {mo }}\end{array}$ & nonirritant $^{5}$ & low $^{3}$ (moderate) $^{5}$ & $\begin{array}{l}\text { non corrosive, } \\
\text { except } \text { iron }^{3}\end{array}$ & $>7$ days $^{5}$ & $\begin{array}{l}\text { very slow }{ }^{1} \\
(\text { slow })^{2}\end{array}$ & \\
\hline
\end{tabular}

${ }^{4}=$ Efficacy of some disinfectant compounds against porcine bacterial pathogens (Thomson et al.). ${ }^{68}$

${ }^{5}=$ Aquatic Veterinary Emergency Plan (Australian Government Department of Agriculture, Fisheries and Forestry). ${ }^{62}$

${ }^{6}=$ Australian Veterinary Emergency Plan (Primary Industries Ministerial Council, Animal Health Australia) ${ }^{6}$ 
Regulations on Food and Animal By-products

Animal by-products and derived products that are excluded from human consumption are part of the regulatory content of Regulation (EC) No 1069/2009 (Animal Byproducts Regulation). ${ }^{34}$ Article 7 of this regulation assigns different materials of animal origin to 1 of 3 categories. These categories reflect the level of risk posed to public and animal health. The prescribed handling of the materials differs depending on the category. According to article 9, animals and parts of animals that have been culled for disease control purposes have to be handled and disposed of as category 2 material-for example, by incineration, burial, composting, or biogas transformation, partly with or without prior pressure sterilization (mainly articles 13 and 19). ${ }^{34}$

While products of animal origin from infected premises come under Regulation (EC) No 1069/2009 and are to be treated accordingly, Council Directive 2002/99/EC on products of animal origin for human consumption contains further specifications for products from territories under animal health restrictions. ${ }^{36}$ This directive allows member states to process and distribute products of animal origin from a territory under animal health restrictions as long as specific conditions are fulfilled (article 4). One of these conditions is that the products do not descend from a holding that keeps infected or suspected animals. A second requirement is that the products undergo a treatment in accordance with annex III of Council Directive 2002/99/ EC. This annex provides detailed recommendations for the treatment of milk and meat such as maturation, fermentation, or heat treatment to eliminate specific pathogens (see Table 1).

With regard to decontamination in the food industry, Regulation (EC) No 178/2002 33 and Regulation (EC) No $852 / 2004^{32}$ mainly comprise specifications on safe food, responsibilities of food producers, and technical conditions in food-producing companies that constitute the prerequisite for a successful disinfection. However, no instructions are provided for decontamination processes in either regulation.

The references above describe primarily physical means for decontamination for different contaminated materials, but no recommendations on chemical disinfection are provided.

\section{Directives for Control of Individual Animal Diseases}

A number of directives exist for the control of individual animal diseases, ${ }^{24,37-43}$ but the level of detail in the directives varies. At one end of the range, the recommendations are general, as in the Council Directive 92/119/EEC for the control of certain animal diseases and swine vesicular disease, in which the extent of decontamination is mentioned without describing disinfection measures. ${ }^{24}$ At the other end, for example, is the Council Directive 2003/85/EC for the control of foot-and-mouth disease, which provides advice on the disinfection of infected holdings and detailed information on how to destroy the virus in slurry, manure, bedding, and forage as well as meat, milk, and other products of animal origin (mainly articles 10, 11 and annexes IV, VII-IX). ${ }^{40}$

In addition, directives are available for the control of avian influenza, African and classical swine fever, and Newcastle and bluetongue disease, giving some advice for decontamination purposes. ${ }^{37-39,41-43}$ Newcastle and bluetongue disease are also covered by the more general Council Directive 92/119/EEC together with vesicular stomatitis, goat pox, peste des petits ruminants, and rinderpest.

Regarding all surveyed legislative references, for 10 of the 23 listed priority agents, disease-specific information can be found for decontamination purposes (see Table 1 for an overview on the relevant directives). However, no European legislation is available for the remaining 13 priority agents listed in Table 1, which is especially remarkable for brucellosis and $\mathrm{Q}$ fever considering the geographical distribution, the economic impact, and the zoonotic potential of these diseases. In most of the disease-specific directives, information on disinfection procedures for different settings or materials can be found, but no specific chemical disinfectants are named.

\section{Legal Restrictions}

In addition to the specific pathogen or situational issues, legal limitations may also influence the choice of a disinfectant. Whatever chemical substance is found suitable for decontamination, its application could be legally restricted. In the EU active substances of disinfectants are regulated by Council Directive 98/8/EC (Biocides Directive). ${ }^{35}$ According to this directive, only those substances are marketable that are listed in annex I or annex Ia of Council Directive 98/8/EC, or in the list of participants and applicants of Regulation (EC) No 1451/2007 (by producttypes) ${ }^{51}$ and are not part of the noninclusion list of Council Directive 98/8/EC. Because of these limitations, ethanol, citric acid, and sodium hydroxide, for example, are not marketable for use in animal husbandry.

However, citric acid is a mild, easily applicable, and very effective disinfectant against $\mathrm{pH}$-sensitive agents, such as the foot-and-mouth disease virus. Sodium hydroxide shows a low sensitivity against organic matter and is still efficient at low temperatures. Thus, sodium hydroxide constitutes an important means of slurry disinfection.

From September 1, 2013, Regulation (EU) No 528/ 2012 (Biocides Regulation) $^{31}$ will replace Directive 98/8/ EC. For emergency cases, article 55 of Regulation (EU) No $528 / 2012$ presents the possibility for the competent authority to permit a limited and controlled use of a biocidal product that is not marketable. Nevertheless, considering the urgency of stopping disease spread in an outbreak situation, the delay caused by a product authorization would be unacceptable.

Despite the comprehensive recommendations in some of the directives mentioned above, almost none of them 
names specific disinfectants and conditions for their application. Whereas laws constitute general abstract rules that are not primarily intended to give specific instructions, the following guidelines of animal health organizations and authorities are more practical.

\section{Recommendations from Organizations}

The literature search for official guidelines for decontamination resulted in the following collection of recommendations from national and international organizations and authorities:

1. Guideline on Means and Procedures for the Disinfection of Notifiable Animal Diseases (BMELV). The Guideline by the German Federal Ministry of Food, Agriculture and Consumer Protection (BMELV) ${ }^{46}$ provides recommendations on the general approach to cleaning and disinfection in animal husbandry. Special attention is paid to the decontamination of buildings, equipment, vehicles, manure, and slurry; decreasing efficiency of chemicals at low temperatures is also addressed. Moreover, it contains individual decontamination protocols for 44 animal diseases that are notifiable in Germany. The protocols are structured into the stages of disinfestation, running, preliminary, and final disinfection including cleaning, surface disinfection, and manure and slurry disinfection. The protocols provide data on efficient chemical substances, applicable concentrations, and contact times and a reference to commercial disinfectants listed by the German Veterinary Society (DVG). ${ }^{52,53}$

The DVG lists include commercial disinfectants for animal husbandry and food production along with distributers of the disinfectants. All of the products included in the lists must comply with the current DVG guidelines for efficacy testing. These tests meet EU standards and even go beyond them, which means further test temperatures, more test viruses, and the additional use of wooden germ carriers to simulate the conditions in animal husbandry more realistically. ${ }^{54}$ However, the DVG lists as well as the BMELV are currently available only in German.

2. Operational Procedures Manual: Decontamination (AUSVETPLAN). The Operational Procedures Manual: Decontamination (Version 3.2) is part of the 3rd edition of the Australian Veterinary Emergency Plan (AUSVETPLAN), which constitutes the national contingency planning framework for the management of animal disease emergencies in Australia. ${ }^{6}$ Besides provisions for disease containment strategies, the AUSVETPLAN includes an operational procedures manual with sections on destruction, disposal, and decontamination. The decontamination part discusses different classes of disinfectants with safety precautions and special advice for the handling of formaldehyde gas (appendix 3). Instructions are given on planning and implementation of the decontamination procedure in different settings such as premises, vehicles, machinery, personal decontamination, and animal by-products. Finally, detailed protocols are presented for the so-called emergency animal diseases in Australia advising applicable disinfectants, concentrations, and contact times. The recommendations are structured according to different items to be disinfected such as carcasses, housing, (electrical) equipment, water tanks, feed, effluent/manure, vehicles, or aircraft.

3. Manual on Procedures for Disease Eradication by Stamping Out (FAO). The FAO Manual ${ }^{47}$ provides advice on the destruction and disposal of animals, going into detail for different methods and sites (parts 1 and 2). Procedures are described for personal decontamination, building and vehicle/machinery decontamination, as well as decontamination of animal effluent, feed, milk, and dairy equipment (chapter 4). Specifications on the handling of certain disinfectants and epidemiologic information on a number of pathogens are included, and detailed protocols for these pathogens are presented with regard to applicable disinfectants, concentrations, and contact times for different items (chapter 2). As the FAO Manual is based on the AUSVETPLAN, these recommendations differ only slightly in the specifications on concentrations and contact times, both of which tend to be slightly higher in the FAO guidelines. This is probably a result of considering lower application temperatures when adapting the AUSVETPLAN to use in any country by the FAO. $^{47}$

The references mentioned so far in this section constitute detailed recommendations focusing on the practical implementation of the decontamination process for numerous animal diseases. Thus, they include valuable advice for practitioners, ranging from manure to aircraft disinfection, discussing advantages and disadvantages of chemicals, and even providing support for the purchase of disinfectants and technical equipment.

4. Technical Disease Cards (OIE). The OIE Technical Disease Cards ${ }^{49}$ provide specific information on 33 animal pathogens, 32 of which are OIE-listed diseases. The cards are structured into sections on etiology, epidemiology, diagnosis, and prevention and control. The etiology section contains a classification of the agent and specifications on the pathogens' resistance to physical and chemical treatment as well as survival capacities in different settings. Linked to this, inactivating temperature and $\mathrm{pH}$ treatments are described along with suitable classes of chemical disinfectants and applicable concentrations. Proceedings in infected countries as well 
as in outbreak situations are presented in the prevention and control section, accompanied by provisions on sanitary and medical prophylaxis.

5. Technical Factsheets (Iowa State University). The Center for Food Security and Public Health at Iowa State University provides individual Technical Factsheets ${ }^{48}$ for 153 biological agents with animal pathogenic or zoonotic potential, covering all of the listed agents in Table 1. In contrast to the recommendations mentioned elsewhere, not just typical animal diseases are considered but also foodborne pathogens like enterohemorrhagic Escherichia coli (EHEC) O157:H7, rare diseases such as Yersinia pestis, and even toxins like ricin.

Each of the factsheets holds disease-specific data-for example, on the etiology, distribution, prevention, and control of a pathogen accounting for animal and public health aspects, if relevant. Furthermore, provisions are made for decontamination accounting for diverse settings (eg, food, water, environment) and, if necessary, for the different natures of an agent (eg, vegetative cell, spore, toxin). Therefore, suitable chemical disinfectants and their concentrations as well as physical, and especially thermal, treatments are presented.

The OIE Technical disease cards and the Iowa State University Technical Factsheets give a broad overview of all issues that need to be considered in case of a disease occurrence, including decontamination, by summarizing the current scientific literature. But, of course, specific instructions for the decontamination process are limited. For example, no information is provided on characteristics of disinfectants or the practical approach for disinfection. Time specifications for the chemical inactivation are not always given.

6. Terrestrial Animal Health Code (OIE). The OIE Terrestrial Animal Health Code ${ }^{50}$ is a standard-setting framework to improve terrestrial animal health and welfare. The first part of the document contains information on the culling and disposal of animals for disease control purposes and detailed recommendations for the decontamination of Bacillus anthracis (including spores) in manure, bedding, slurry, animal housing, vehicles, and contaminated rooms (chapter 4.13). The second part provides information on OIE-listed diseases and other diseases of importance to international trade (79 pathogens) focusing on trade restrictions caused by their occurrence. It goes into detail for individual products of animal origin from countries or zones with different disease status.

Specifications for the importation of products reveal commodities that bear the risk of spreading disease and are thus important to be decontaminated. In addition, direct instructions are provided for the inactivation of different pathogens, as these inactivation procedures (eg, fermentation, thermal or chemical treatment, irradiation) influence trade restrictions, for example, on meat, milk, and other products and by-products of animal origin.
Compared to the recommendations given above, the OIE Terrestrial Animal Health Code considers special products such as meat and milk products, hides, wool, and bonemeal. Thus, the additional economic perspective of the Health Code provides valuable supplementary information for specific decontamination purposes.

The above results show that a lot of information exists on the decontamination of high-priority animal or zoonotic pathogens. An overview of all recommendations in relation to individual biological agents is presented in Table 1. For a number of agents, several references provide decontamination instructions covering different fields of application from facilities to products of animal origin. However, for some pathogens, a lack of information sources is evident. The following biological agents are considered in only 1 of the reviewed references: Burkholderia pseudomallei, Coxiella burnetii, EHEC O157:H7, Francisella tularensis, Y. pestis, Clostridium botulinum neurotoxin (BoNT), and Staphylococcal enterotoxin B (SEB). These pathogens and toxins are mentioned only in the Iowa State University Technical Factsheets, except for $F$. tularensis, which is also considered in the OIE Terrestrial Animal Health Code. However, the Health Code chapter on tularemia gives no advice on decontamination.

In contrast to the pathogens mentioned before, various recommendations are available for the decontamination of $B$. anthracis. Because of the attacks with letters containing $B$. anthracis spores in the US in 2001, this agent is of special concern. Therefore, several technical reports were published by the US Environmental Protection Agency (EPA) assessing different means and procedures for indoor and outdoor decontamination and accounting for ecological and economical aspects. ${ }^{55-60}$ Hydrogen peroxide and peracetic acid products as well as hypochlorous substances were found to be efficient, ${ }^{56,60}$ as were bleach and chlorine dioxide, which showed inactivating results for $B$. anthracis spores. ${ }^{55,56,58-60}$ The EPA reports are valuable for animal health and for public health issues.

\section{Characteristics of Disinfectants}

As can be seen from Table 1, for most pathogens several references are available that provide information on decontamination. Most of the documents mentioned above suggest a variety of chemical disinfectants for each pathogen. Therefore, the appropriate disinfectant and decontamination strategy must be chosen and adapted to the particular situation. However, a lot of case-related factors have influence on the choice of disinfectant, such as the stability of the pathogen, the extent of contamination, the contaminated material, the presence of inhibitors, the given temperature, and time constrains. With regard to largescale outbreaks or bioterrorist incidents, an ideal disinfectant should have a short minimal exposure time and a wide range of efficacy to avoid the use of several substances (cross-reactions and possible impairment). It should be 
effective at low temperatures, harmless to materials, environment, and humans, easily and broadly applicable, stable for long-term storage, and preferably low priced. ${ }^{5,61}$

Matching situational demands with characteristics of disinfectants determines the suitable approach. Information on disinfectant characteristics can be found in various literature sources, but only a synopsis of data enables an adequate decision. In order to provide a knowledge base and assistance in decision making, important characteristics for the main recommended chemicals from the examined references are summarized in Table 2.

Each of the chemical disinfectants was assessed with regard to its inactivating spectrum, effective $\mathrm{pH}$ range, applicable temperature range, sensitivity against organic matter, and possible inhibitors. These aspects determine whether a disinfectant is generally appropriate for the inactivation of an agent in the given circumstances. The categories health aspects, toxicity to the environment, material tolerance, stability of working solution, reaction time, and costs outline additional situational, ecological, and economic considerations affecting the choice of an active substance. It must be emphasized that especially the categories health aspects, inhibitors, and material tolerance make no claims of being complete.

References are listed in Table 2 for each specification to allow for a more detailed look, if necessary, and to take account of supplementary or even contradictory indications from different literature sources.

In general, it can be stated that all of the listed substances are suitable to inactivating viruses and bacteria, while some of them are only selectively effective against enveloped viruses and not efficient against mycobacteria such as phenols or quaternary ammonium compounds. However, only a few of the chemicals are appropriate for spore inactivation such as aldehydes, sodium hypochlorite, peracetic acid, and iodine to some extent. ${ }^{5,6,46,62}$ Especially for alkalines and organic acids, the $\mathrm{pH}$ range is critical for inactivating efficacy. For example, sodium hydroxide is only effective at a $\mathrm{pH}$ above 12 , which must be observed when disinfecting slurry. In contrast, organic acids work at a $\mathrm{pH}$ range of 2 to 3 . It is self-evident that alkalines and acids neutralize each other, which should be avoided when using different substances simultaneously. 5,6,46,62

With a view to the effective temperature range of the substances, it is obvious that the inactivating activity of disinfectants decreases at low temperatures, so concentrations must be raised for consistent effectiveness. From the listed substances, only sodium hydroxide, lime milk, peracetic acid, and to some extent alcohol and iodine work under temperature conditions below $0^{\circ} \mathrm{C}$. Formaldehyde especially is strongly influenced by low temperatures and does not work properly below $10^{\circ} \mathrm{C},{ }^{5,46}$ which can aggravate the challenge of spore inactivation.

In addition to the temperature and the prevailing $\mathrm{pH}$ affecting the efficacy of disinfectants, the extent of organic contamination also has an effect. Any disinfectant works best on cleaned surfaces. However, there are striking differences in the sensitivity of chemicals against organic matter. Thus, the use of sodium hypochlorite, iodine, and quaternary ammonium compounds is confined due to their decreasing activity in the presence of organic load. When comparing the categories sensitivity against organic matter and toxicity to environment, it seems that these aspects are slightly related. Except for alcohols, peracetic acid, and organic acids, the toxicity is high (or at least moderate) if the sensitivity against organic pollution is low, and vice versa. 5,6,46,54,62 Especially alkalines and phenols can cause severe environmental damages. ${ }^{62}$

Regarding the safety of operators, reasonable care is necessary for the use of any disinfectant. However, special care must be taken for some disinfectants to avoid adverse health effects. In particular, formaldehyde gas should be used only by trained and authorized personnel because of its toxic and carcinogenic properties. $^{6,62}$ The handling and storage of concentrated substances usually needs more caution compared to the use of diluted working solutions. A diluted peracetic acid solution could, for example, be used as a hand disinfectant, while the concentrated acid is highly irritating and corrosive. ${ }^{5}$ The more stable a working solution, the fewer concentrates need to be handled. Thus, the stability of the working solution has an influence on the suitability of a disinfectant.

In addition to health consequences for the user of a disinfectant, effects on materials should not be overlooked. Therefore, the corrosiveness of chemicals may limit the application spectrum (eg, sodium hydroxide and sodium hypochlorite are corrosive to metal alloys). ${ }^{62}$ With regard to the reaction time of disinfectants, it is obvious that it influences the duration of the overall decontamination process and associated measures such as closure of facilities. Moreover, the minimum exposure time also determines directly the possible applications to some degree (eg, for hand disinfection or for drive-through basins, only substances with short inactivation times can be used).

The considerations mentioned above show that many parameters must be evaluated when choosing a disinfectant; this can be a particular challenge in large-scale outbreaks or bioterrorist incidents.

\section{Discussion}

Based on a priority list of 23 biological agents, relevant recommendations for decontamination purposes have been presented and information gaps have been addressed. Moreover, it has been shown that many parameters have to be considered in choosing an appropriate disinfectant. Thus, any decision is a compromise as a result of weighing different requirements.

\section{Availability of Recommendations}

As stated above, the Iowa State University Technical Factsheets are the only identified official reference with 
recommendations for the decontamination of $B$. pseudomallei, C. burnetii, EHEC O157:H7, F. tularensis, Y. pestis, BoNT, and SEB. Even though the Technical Factsheets are very comprehensive, they are not suited for and not intended to consider all aspects connected with the decontamination of these agents. For an adequate decision of a decontamination approach, a broader literature base is needed.

With the exception of EHEC O157:H7, which is mainly pathogenic to humans, all of the agents lacking decontamination instructions are capable of causing illness in both animals and humans. Due to a subclinical course of the disease or a limited host spectrum, the effects on animal health of B. pseudomallei, EHEC O157:H7, F. tularensis, or $Y$. pestis are limited. The same applies for the toxins SEB and BoNT because they are not contagious. Nevertheless, the risk caused to human public health by these agents cannot be neglected. This aspect is also reflected in the list of bioterrorism agents and diseases from the US Centers for Disease Control and Prevention (CDC), ${ }^{12}$ where F. tularensis, $Y$. pestis, and BoNT are assigned to category A (highest priority) and B. pseudomallei, E. coli O157:H7, and SEB are mentioned in category B. Unlike the previously discussed agents, C. burnetii, the causative agent of $\mathrm{Q}$ fever (CDC category B), poses a risk to both public and animal health. The lack of decontamination protocols for C. burnetii was recently addressed by the Central Veterinary Institute (CVI) in the Netherlands. In a study by de Jong, the peroxygen-based commercial disinfectant Virkon-S was successfully tested for efficacy against $C$. burnetii. ${ }^{63}$

Except for B. pseudomallei and SEB, the occurrence of human disease caused by one of the discussed pathogens and toxins is notifiable to the human public health authorities in Germany. Therefore, the recommendations on disinfection provided by the German Robert Koch Institute (RKI) ${ }^{64}$ can be helpful as well as the list of certificated disinfectants by the German Association for Applied Hygiene $(\mathrm{VAH}) .{ }^{65}$ Another reference that at least addresses decontamination to some extent is the joint guideline of the German Federal Office of Civil Protection and Disaster Assistance (BBK) and RKI with provisions on medical procedures in case of bioterrorism incidents. ${ }^{66}$ However, the scope of these recommendations is human public health, and the recommendations are not directly applicable to the animal health sector.

\section{Challenges in the Choice of Disinfectant}

Every disinfectant has advantages and disadvantages and is therefore suitable for different situations. The demands on a suitable disinfectant for large-scale outbreaks or bioterrorism incidents are numerous: short minimal exposure time; wide range of efficacy; broad temperature range; harmless to materials, environment, and humans; easy and broad ap- plicability; stable for long-term storage; low priced. ${ }^{5,61} \mathrm{Un}$ fortunately, no single substance meets all of these demands. This underlines the necessity of finding the appropriate (if not the ideal) disinfectant for the specific situation.

When trying to match requirements with characteristics listed in Table 2, peracetic acid is a positive example. Peracetic acid is effective against a wide range of organisms including bacterial spores and also in inactivating botulinum toxins, and the necessary exposure time is short. It is still active at low temperatures and has a low sensitivity against organic contamination with the exception of blood residues. Furthermore, the working solution of peracitic acid is nonallergenic, a low irritant, and has a low toxicity to the environment as it degrades into water and acetic acid. ${ }^{5}$ These ecological and health compatible properties, along with the wide temperature range of peracetic acid, are advantages compared to, for example, formaldehyde, which is similarly efficient against spores.

Due to these characteristics, peracetic acid is generally suitable for various applications in animal husbandry as well as in the food industry such as the disinfection of surfaces, vehicles, rooms, instruments, clothing and protective wear, hands and skin, and even wastewater to some extent. $^{5,62}$ However, different concentrations and contact times are required for specific applications, and tolerance of materials as well as safety aspects have to be considered.

A disadvantage of peracetic acid is the low stability of the working solution. This requires a preparation of fresh working solution every 1 to 3 days from concentrated acid, which requires more cautious handling as it is highly corrosive and can cause damage to health. ${ }^{5,46,62}$ Alkalized peracetic acid is effective at slightly longer exposure times but is less corrosive and has a less penetrating smell. ${ }^{5}$ Another negative factor compared to formaldehyde is the missing data for the use of peracetic acid as a fumigant. 5,62

Despite these drawbacks, the efficacy of this substance has already been proven under practical conditions during an outbreak of avian influenza (H5N1) in Germany in 2006, where peracetic acid was broadly applied by operational forces. ${ }^{5,67}$

This article attempts to give stakeholders and decision makers an overview of existing recommendations and their focus of application for the decontamination of high-risk animal and zoonotic pathogens. Besides the presentation of relevant references and legislation, the survey revealed a lack of information sources for a number of biological agents such as B. pseudomallei, C. burnetii, EHEC O157:H7, F. tularensis, $Y$. pestis, BoNT, and SEB. Especially for $C$. burnetii and Brucella spp., it is remarkable that no legislation is available at the EU level for the control of these pathogens since these agents can induce severe diseases and cause high economic losses. The identification of these weak points can contribute to optimizing preparedness for a crisis situation through further efforts to reduce information gaps.

With regard to legal restrictions for the use of disinfectants, it is important that EU legislation such as the Biocides 
Regulation does not conflict with official recommendations for efficient chemicals. A harmonization of legally permitted and officially advised disinfectants would give operators the necessary confidence to act in a timely way in crisis situations.

The compilation of requirements on disinfectants for large-scale incidents illustrates the challenge of choosing an appropriate mean for decontamination. Therefore, the collection of characteristics of important chemical disinfectants can serve as decision support for the choice of a suitable and efficient approach to mitigating the consequences of crisis situations induced by high-risk animal or zoonotic pathogens.

\section{ACKNOWLEDGMENTS}

This research was supported by/executed in the framework of the EU project AniBioThreat (Grant Agreement: Home/ 2009/ISEC/AG/191) with financial support from the Prevention of and Fight against Crime Programme of the European Union, European Commission-Directorate General Home Affairs. This publication reflects the views only of the authors, and the European Commission cannot be held responsible for any use that may be made of the information contained therein.

\section{REFERENCES}

1. Yeoman I, Lennon JJ, Black L. Foot-and-mouth disease: a scenario of reoccurrence for Scotland's tourism industry. Journal of Vacation Marketing 2005;11:179-190.

2. Anderson I. Foot and Mouth Disease 2001: Lessons to Be Learned Inquiry. London: Stationery Office; 2002. http:// webarchive.nationalarchives.gov.uk/20100807034701/http:// archive.cabinetoffice.gov.uk/fmd/fmd_report/report/index. htm. Accessed July 31, 2013.

3. Ssematimba A, Elbers AR, Hagenaars TJ, de Jong MC. Estimating the per-contact probability of infection by highly pathogenic avian influenza (H7N7) virus during the 2003 epidemic in the Netherlands. PLoS One 2012;7(7):e40929.

4. van der Hoek W, Schneeberger PM, Oomen T, et al. Shifting priorities in the aftermath of a $\mathrm{Q}$ fever epidemic in 2007 to 2009 in the Netherlands: from acute to chronic infection. Euro Surveill 2012;17(3):20059.

5. Federal Office of Civil Protection and Disaster Assistance and Robert Koch Institute, Germany. [Disinfection and decontamination in biological incidents by operational forces. Biological Hazards I, Manual for Civil Protection] [in German]. 2007. http://www.bbk.bund.de/SharedDocs/ Downloads/BBK/DE/Publikationen/PublikationenForschung/ BioGef-I_3Auflage.pdf?__blob = publicationFile. Accessed July 31, 2013.

6. Australian Veterinary Emergency Plan (AUSVETPLAN). Operational Procedures Manual: Decontamination (Version 3.2). Canberra: ACT, Animal Health Australia; 2008. http:// www.animalhealthaustralia.com.au/. Accessed July 31, 2013.

7. Council conclusions on strengthening chemical, biological, radiological and nuclear (CBRN) security in the European
Union - an EU CBRN Action Plan. Adoption. 12-11-2009. http://register.consilium.europa.eu/pdf/en/09/st15/st15505re01.en09.pdf.

8. Federal Ministry of Food Agriculture and Consumer Protection, Germany. [Contribution for early detection of bioterroristic attacks on the food chain - A handbook] [in German]. 2008.

9. World Organization for Animal Health (OIE). Old classification of diseases notifiable to the OIE. 2004. http:// www.oie.int/animal-health-in-the-world/the-world-animalhealth-information-system/old-classification-of-diseases-notifiableto-the-oie-list-a/. Accessed July 31, 2013.

10. Australia Group. List of Biological Agents for Export Control. Updated March 2013. http://www.australiagroup.net/ en/biological_agents.html. Accessed July 31, 2013.

11. Australia Group. List of Animal Pathogens for Export Control. Updated July 2013. http://www.australiagroup.net/ en/animal.html. Accessed July 31, 2013.

12. Centers for Disease Control and Prevention (CDC). Bioterrorism Agents/Diseases. 2007. http://emergency.cdc.gov/ agent/agentlist-category.asp. Accessed July 31, 2013.

13. Federal Office of Public Health, Switzerland, [B-Terrorism and Food] [in German]. 2004.

14. United States Department of Agriculture (USDA) and Department of Health \& Human Services (HHS). HHS and USDA select agents and toxins. 2008. http://www.selectagents. gov/resources/List $\% 20$ of $\% 20$ Select $\% 20$ Agents $\% 20$ and $\% 20$ Toxins_111708.pdf. Accessed July 31, 2013.

15. Anti-Terrorism, Crime and Security Act, Chapter 24. 2001. http://www.legislation.gov.uk/ukpga/2001/24/pdfs/ukpga_ 20010024_en.pdf. Accessed July 31, 2013.

16. UN 2814: infectious substances affecting humans.

17. UN 2900: infectious substances affecting animals.

18. Council Directive 82/894/EEC of 21 December 1982 on the noitification of animal diseases within the Community. 1982. http://eur-lex.europa.eu/LexUriServ/LexUriServ.do?uri $=$ OJ:L:1982:378:0058:0062:EN:PDF. Accessed July 31, 2013.

19. Directive 2000/54/EC of the European Parliament and of the Council of 18 September 2000 on the protection of workers from risks related to exposure to biological agents at work. 2000. http://eur-lex.europa.eu/LexUriServ/LexUriServ. do?uri=OJ:L:2000:262:0021:0045:EN:PDF. Accessed July 31, 2013.

20. Federal Institute for Occupational Safety and Health (BAuA), Germany, [Technical Rules for Biological Agents (TRBA 466)] [in German]. 2010. http://www.baua.de/de/ Themen-von-A-Z/Biologische-Arbeitsstoffe/TRBA/pdf/TRBA466.pdf?_blob $=$ publicationFile $\% 26 \mathrm{v}=6$.

21. Federal Institute for Occupational Safety and Health (BAuA), Germany, [Technical Rules for Biological Agents (TRBA 462)] [in German]. 2010. http://www.baua.de/de/ Themen-von-A-Z/Biologische-Arbeitsstoffe/TRBA/pdf/TRBA462.pdf?_blob $=$ publicationFile $\% 26 \mathrm{v}=4$.

22. [Regulation on notifiable animal diseases] [in German]. 2011. http://www.gesetze-im-internet.de/bundesrecht/tierseuchanzv/ gesamt.pdf. Accessed July 31, 2013.

23. [Law on preventing and combating infectious diseases in humans (IfSG)] [in German]. 2000. http://www.gesetze-iminternet.de/bundesrecht/ifsg/gesamt.pdf. Accessed July 31, 2013.

24. Council Directive 92/119/EEC of 17 December 1992 introducing general community measures for the control of 
certain animal diseases and specific measures relating to swine vesicular disease. 1992. http://eur-lex.europa.eu/Lex UriServ/LexUriServ.do?uri = OJ:L:1993:062:0069:0085:EN: PDF. Accessed July 31, 2013.

25. National Institute of Allergy and Infectious Diseases. NIAID Category A, B, and C Priority Pathogens. 2012. http:// www.niaid.nih.gov/topics/biodefenserelated/biodefense/pages/ cata.aspx. Accessed July 31, 2013.

26. Blancou J, Pearson JE. Bioterrorism and infectious animal diseases. Comp Immunol Microbiol Infect Dis 2003; 26(5-6):431-443.

27. United Nations. Chemical and bacteriological (biological) weapons and the effects of their possible use: Report of the Secretary-General, New York. 1969.

28. World Health Organization (WHO). Health aspects of chemical and biological weapons: Report of a WHO group of consultants. Geneva. 1970.

29. NATO Handbook on the Medical Aspects of NBC Defensive Operations, Part II-Biological. 1996.

30. Ad Hoc Group of the States Parties to the Convention on the Prohibition, Development Production and Stockpiling of Bacteriological Biological and Toxin Weapons and on their Destruction, document BWC/AD HOC GROUP/56-2, at pp 465-466, which is in Annex A of the Chairman's Composite Text for the BWC Protocol. 2001.

31. Regulation (EU) No 528/2012 of the European Parliament and of the Council of 22 May 2012 concerning the making available on the market and use of biocidal products. June 27, 2012. http://eur-lex.europa.eu/LexUriServ/LexUriServ. do?uri=OJ:L:2012:167:FULL:EN:PDF. Accessed July 31, 2013.

32. Regulation (EC) No 852/2004 of the European Parliament and of the Council of 29 April 2004 on the hygiene of foodstuffs. 2004. http://eur-lex.europa.eu/LexUriServ/ LexUriServ.do?uri= OJ:L:2004:139:0001:0054:EN:PDF. Accessed July 31, 2013.

33. Regulation (EC) No 178/2002 of the European Parliament and of the Council of 28 January 2002 laying down the general principles and requirements of food law, establishing the European Food Safety Authority and laying down procedures in matters of food safety. 2002. http://eur-lex.europa. eu/LexUriServ/LexUriServ.do?uri = OJ:L:2002:031:0001:0024: EN:PDF. Accessed July 31, 2013.

34. Regulation (EC) No 1069/2009 of the European Parliament and of the Council of 21 October 2009 laying down health rules as regards animal by-products and derived products not intended for human consumption and repealing Regulation (EC) No 1774/2002 (Animal by-products Regulation). 2009. http://eur-lex.europa.eu/LexUriServ/LexUriServ.do? uri=OJ:L:2009:300:0001:0033:EN:PDF. Accessed July 31, 2013.

35. Directive 98/8/EC of the European Parliament and of the Council of 16 February 1998 concerning the placing of biocidal products on the market. 1998. http://eur-lex.europa. eu/LexUriServ/LexUriServ.do?uri= OJ:L:1998:123:0001:0063: EN:PDF. Accessed July 31, 2013.

36. Council Directive 2002/99/EC of 16 December 2002 laying down the animal health rules governing the production, processing, distribution and introduction of products of animal origin for human consumption. 2002. http://eur-lex. europa.eu/LexUriServ/LexUriServ.do?uri = CELEX:32002L0099: en:NOT. Accessed July 31, 2013.
37. Commission Regulation (EC) No $1266 / 2007$ of 26 October 2007 on implementing rules for Council Directive 2000/75/ EC as regards the control, monitoring, surveillance and restrictions on movements of certain animals of susceptible species in relation to bluetongue. 2007. http://eur-lex.europa.eu/ LexUriServ/site/en/oj/2007/1_283/1_28320071027en00370052. pdf. Accessed July 31, 2013.

38. Council Directive 2001/89/EC of 23 October 2001 on Community measures for the control of classical swine fever. 2001. http://eur-lex.europa.eu/LexUriServ/LexUriServ.do?uri = OJ:L:2001:316:0005:0035:EN:PDF. Accessed July 31, 2013.

39. Council Directive 2002/60/EC of 27 June 2002 laying down specific provisions for the control of African swine fever and amending Directive 92/119/EEC as regards Teschen disease and African swine fever. 2002. http://eur-lex.europa.eu/ LexUriServ/LexUriServ.do?uri = OJ:L:2002:192:0027:0046: EN:PDF. Accessed July 31, 2013.

40. Council Directive 2003/85/EC of 29 September 2003 on Community measures for the control of foot-and-mouth disease repealing Directive 85/511/EEC and Decisions 89/ 531/EEC and 91/665/EEC and amending Directive 92/46/ EEC. 2003. http://eur-lex.europa.eu/LexUriServ/LexUriServ. do?uri= OJ:L:2003:306:0001:0087:EN:PDF. Accessed July 31, 2013.

41. Council Directive 2005/94/EC of 20 December 2005 on Community measures for the control of avian influenza and repealing Directive 92/40/EEC. 2005. http://eur-lex.europa. eu/LexUriServ/LexUriServ.do?uri= OJ:L:2006:010:0016:0065: EN:PDF. Accessed July 31, 2013.

42. Council Directive 92/66/EEC of 14 July 1992 introducing Community measures for the control of Newcastle disease. 1992. http://eur-lex.europa.eu/LexUriServ/LexUriServ.do?uri $=$ OJ:L:1992:260:0001:0020:EN:PDF. Accessed July 31, 2013.

43. Council Directive 2000/75/EC of 20 November 2000 laying down specific provisions for the control and eradication of bluetongue. 2000. http://eur-lex.europa.eu/LexUriServ/ LexUriServ.do?uri= OJ:L:2000:327:0074:0083:EN:PDF. Accessed July 31, 2013.

44. http://eur-lex.europa.eu/de/index.htm. Accessed July 31, 2013.

45. http://www.mugv.brandenburg.de/cms/detail.php/lbm1.c. 319600.de. Accessed July 31, 2013.

46. Federal Ministry of Food Agriculture and Consumer Protection (BMELV), Germany, [Guideline on means and procedures for the disinfection of notifiable animal diseases] [in German]. 2007. http://www.bmelv.de/SharedDocs/ Downloads/Landwirtschaft/Tier/Tiergesundheit/Tierseuchen/ Infektionsrichtlinie.pdf?_blob= publicationFile. Accessed July 31, 2013.

47. Food and Agriculture Organization of the United Nations (FAO). Manual on Procedures for Disease Eradication by Stamping Out, Part 3: Decontamination Procedures. 2001. http://www.fao.org/docrep/004/Y0660E/Y0660E03.htm\#ch3. Accessed July 31, 2013.

48. Spickler AR. Technical Factsheets. http://www.cfsph.iastate. edu/DiseaseInfo/factsheets.php. Accessed July 31, 2013.

49. World Organization for Animal Health (OIE). Technical disease cards. 2012. http://www.oie.int/animal-health-in-theworld/technical-disease-cards/. Accessed July 31, 2013.

50. World Organization for Animal Health (OIE). Terrestrial Animal Health Code-Recommendations applicable to 
OIE. Listed diseases and other diseases of importance to international trade. 2012. http://www.oie.int/internationalstandard-setting/terrestrial-code/access-online/. Accessed July 31, 2013.

51. List of participants and applicants whose dossiers are being examined under the Review Programme for existing active substances used in biocidal products (Substances classified by product-types). 2012. http://ec.europa.eu/environment/ biocides/pdf/list_participants_applicants_prod.pdfhttp://ec. europa.eu/environment/biocides/pdf/list_participants_applicants_ prod.pdf.

52. German Veterinary Society (DVG). [ $8^{\text {th }}$ List of disinfectants for the food industry (commercial products) tested based on the guidelines of the DVG (Edition 4, 2007) and found to be effective] [n German]. 2012. http://www.dvg.net/ fileadmin/Bilder/DVG/PDF/12-10-08-LM8-Homepage. pdf. Accessed July 31, 2013.

53. German Veterinary Society (DVG). $\left[13^{\text {th }}\right.$ List of disinfectants for the animal husbandry (commercial products) tested based on the guidelines of the DVG and found to be effective] [in German]. 2012. http://www.dvg.net/fileadmin/ Bilder/DVG/PDF/12-10-13-TH13-Homepage.pdf. Accessed July 31, 2013.

54. German Veterinary Society (DVG). [Special Issue "Disinfection”] [in German]. 2011. http://www.dvg.net/index. php?id=1117. Accessed July 31, 2013.

55. Calfee MW, Ryan SP, Wood JP, et al. Laboratory evaluation of large-scale decontamination approaches. J Appl Microbiol 2012;112(5):874-882.

56. US Environmental Protection Agency (EPA). Determining the Efficacy of Liquids and Fumigants in Systematic Decontamination Studies for Bacillus anthracis Using Multiple Test Methods. 2010. http://cfpub.epa.gov/si/si_public_file_ download.cfm?p_download_id=507838. Accessed July 31, 2013.

57. US Environmental Protection Agency (EPA). Ozone Gas Decontamination of Materials Contaminated with Bacillus anthracis Spores. 2011. http://cfpub.epa.gov/si/si_public_ file_download.cfm?p_download_id $=504224$. Accessed July 31, 2013.

58. US Environmental Protection Agency (EPA). Assessment of Liquid and Physical Decontamination Methods for Environmental Surfaces Contaminated with Bacterial Spores Development and Evaluation of the Decontamination Procedural Steps. 2012. http://cfpub.epa.gov/si/si_public_file_download.cfm? p_download_id=505995. Accessed July 31, 2013.

59. US Environmental Protection Agency (EPA). Assessment of Liquid and Physical Decontamination Methods for Environmental Surfaces Contaminated with Bacterial Spores: Evaluation of Spray Method Parameters and Impact of Surface Grime. 2012. http://cfpub.epa.gov/si/si_public_ file_download.cfm?p_download_id $=507933$.

60. Wood JP, Choi YW, Rogers JV, Kelly TJ, Riggs KB, Willenberg ZJ. Efficacy of liquid spray decontaminants for in- activation of Bacillus anthracis spores on building and outdoor materials. J Appl Microbiol 2011;110(5):1262-1273.

61. Nattermann H, Becker S, Jacob D, Klee SR, Schwebke I, Appel B. [Efficient inactivation of anthrax spores by aqueous and alcoholic peracetic acid solutions] [in German]. Bundesgesundheitsblatt - Gesundheitsforschung - Gesundheitsschutz 2005;48(8):939-950. http://www.springerlink.com/content/ j915053273735120/. Accessed July 31, 2013.

62. Australian Government Department of Agriculture, Fisheries and Forestry. Canberra ACT. Operational Procedures Manual - Decontamination (Version 1.0). In: Australian Aquatic Veterinary Emergency Plan (AQUAVETPLAN). 1 http://www.daff.gov.au/aquavetplan. Accessed July 31, 2013.

63. de Jong R; Central Veterinary Institute (CVI), The Netherlands. Determination of veterinary bactericidal activity of Virkon-S against Coxilla burnetii in high soiling conditions. 2011. http://www.falw.vu/dida/protocol/Virkon_S_v_ Coxiella_Burnetii.pdf. Accessed July 31, 2013.

64. Robert Koch Institute, Germany. [List of certified and approved disinfectants and procedures by the Robert Koch Institute] [in German]. 2007. http://www.rki.de/DE/ Content/Infekt/Krankenhaushygiene/Desinfektionsmittel/ Desinfektionsmittelliste.pdf?__blob = publicationFile. Accessed July 31, 2013.

65. Association for Applied Hygiene (VAH). VAH List of Disinfectants. 2012. http://www.vah-online.de/. Accessed July $31,2013$.

66. Federal Office of Civil Protection and Disaster Assistance and Robert Koch Institute, Germany. [Known Pathogens / Disease specific aspects. Biological Hazards II, Decision support for medical procedures for bioterroristic incidents] (in German) p. 98 235. 2007. http://www.bbk.bund. de/SharedDocs/Downloads/BBK/DE/Publikationen/Publikation enForschung/BioGefahren-II-MedVers.pdf;jsessionid = FB485A9A440626BBC092866F72C151B2.1_cid355?_blob= publicationFile. Accessed July 31, 2013.

67. Steffler R, Thomas T, Medicke G. [Avian influenza in livestock in Saxony, activities of the fire brigade] [in German]. 2006. http://www.bbk.bund.de/SharedDocs/Downloads/BBK/ DE/Publikationen/Publ_magazin/bsmag_3_06.pdf?_blob= publicationFile. Accessed July 31, 2013.

68. Thomson JR, Bell NA, Rafferty M. Efficacy of some disinfectant compounds against porcine bacterial pathogens. Pig Journal 2007;60.

Manuscript received December 14, 2012;

accepted for publication June 3, 2013.

Address correspondence to: Hendrik Frentzel Federal Institute for Risk Assessment, Biological Safety Max-Dohrn-Str. 8-10 Berlin 10589 Germany

E-mail: Hendrik.Frentzel@bfr.bund.de 